EXTENDED REPORT

\title{
Non-specific tolerance induced by staphylococcal enterotoxin B in treating high risk corneal transplantation in rats
}

\author{
Y Jie, Z Pan, Y Chen, Y Wei, W Zhang, Y Wu, H Peng, L Xu
}

Br J Ophthalmol 2005;89:364-368. doi: 10.1136/bjo.2004.048959

See end of article for authors' affiliations

authors afiliations

Correspondence to:

Zhiqiang Pan, Beiijing Institute of Ophthalmology and the Beiiing TongRen Eye Bank, Beijing TongRen Eye Centre, Beijing TongRen Hospital, Capital University of Medical Sciences, China; panzhq@trhos.com

Accepted for publication 1 August 2004
Aims: To explore the role of staphylococcal enterotoxin B (SEB) in treating high risk corneal keratoplasty in rats.

Methods: Rat corneal high risk transplantation rejection models were set up using Fisher 344 and Lewis rats. The experimental rats were injected intraperitoneally with $0.2 \mathrm{ml} \mathrm{SEB}$ at different concentrations before keratoplasty. The rejection indexes of the allograft were recorded and the lymphocyte infiltration in the allograft and the percentage of the lymphocyte subpopulation in the lymphatic organs were also examined. Lymphocyte proliferation ability and the concentration of IL-2 and IL-10 in the serum were also evaluated.

Results: Compared with the control group, SEB prolonged the survival time of the allograft significantly from 7 to 12 days. It could also reduce $C D 4^{+}$and $C D 8^{+}$lymphocyte infiltration in the allograft and minimise the percentage of $\mathrm{CD}^{+}$and $\mathrm{CD} 8^{+}$lymphocytes in the lymphatic organs. The lymphocyte proliferation ability was also weakened. However, the percentage of CD4 ${ }^{+} \mathrm{NK}$ T lymphocytes in the lymphatic organs was raised. The serum concentration of IL-10 was higher but IL-2 was lower in the SEB treated groups.

Conclusions: SEB prolonged the survival time of the allograft in high risk rat corneal allo-transplantation, which may be caused by $T$ cell deletion and acquisition of non-specific tolerance.
C orneal transplantation had emerged as the most common and successful form of solid tissue transplantation. In uncomplicated first allograft performed in avascular beds, the 2 year survival rate is over $90 \% .^{1}$ But there are still a significant number of corneal grafts that have experienced at least one rejection episode. This immunological threat to graft survival is nowhere more evident than in vascularised recipient beds, which makes the allograft a high risk with earlier and more serious rejection episodes that are more resistant to therapy. ${ }^{2}{ }^{3}$

There are several ways to enhance corneal allograft survival by immune modulation, including preventing the induction of alloimmune response, disruption of effectors $\mathrm{T}$ cells, induction of anterior chamber associated immune deviation (ACAID) and oral tolerance. ${ }^{4}$ Until now, there have been few reports of inducing non-specific anergy to prolong the survival of allografts in corneal allo-transplantation.

Staphylococcal enterotoxin B (SEB) is a bacterially derived superantigen. It can bypass classic MHC class I and II restrictions and interact with both $\mathrm{CD}^{+}$and $\mathrm{CD} 8^{+} \mathrm{T}$ cells. $\mathrm{T}$ cells respond to SEB stimulation with profound cytokine production and proliferation. ${ }^{5}$ But SEB activation of T cells is transient; repeated challenges with SEB can induce $\mathrm{T}$ cell deletion and anergy. ${ }^{6}$

In our previous report, SEB was given to treat normal corneal transplantation immune rejection and could prolong the survival time of the allografts. ${ }^{7}$ But, whether SEB could prolong the graft survival in high risk corneal transplantation and its mechanism of action is still unknown. In this experiment, the role of SEB in treating high risk keratoplasty was explored.

\section{MATERIALS AND METHODS}

\section{Animals}

Fisher $344\left(\mathrm{RTl}^{\mathrm{Vl}}\right)$ inbred rats were used as donors and Lewis $\left(\mathrm{RTI}^{\mathrm{le}}\right)$ inbred rats were used as recipients. All rats were female, 8 10 weeks of age, and 160-180 g body weight. All the animals were purchased from the animal institute of the Chinese Medical Academy, Beijing, China. All animals were treated in accordance with the ARVO statement on the use of animals in ophthalmic and vision research.

\section{Induction of corneal neovascularisation}

Corneal neovascularisation was induced by intrastromal sutures as described. ${ }^{8}$ Briefly, three interrupted 10-0 silk sutures were placed in the central corneas of the recipients rats. Seven days later, neovessels entered the mid-peripheral zone from the limbus. Only rats with neovessels in all four quadrants served as recipients of orthotropic keratoplasty (fig 1A)

\section{Orthotropic corneal transplantation}

Orthotropic corneal transplantation was performed as described previously. ${ }^{9}$ Each animal was deeply anaesthetised with an intramuscular injection of ketamine and xylazine before all surgical procedures. The $3 \mathrm{~mm}$ donor central cornea was excised and stored in Optisol solution. The recipient graft bed was prepared by $2.5 \mathrm{~mm}$ excision of the central cornea. The donor button was then secured in place with eight interrupted 10-0 silk sutures. Antibiotic ointment was applied to the corneal surface, and the eyelids were shut for 24 hours with tarsorrhaphy. Transplant sutures were kept in place and not removed.

\section{Assessment of rejection}

From the first day after keratoplasty, grafts were examined and scored by slit lamp microscopy every day till graft

Abbreviations: ACAID, anterior chamber associated immune deviation; BSA, bovine serum albumin; ConA, concanavalin-A; ELISA, enzyme linked immunosorbent assay; HRP, horseradish peroxidase; $M T T$, methyl thiazolyl tetrazolium; NK, natural killer; OD, optical density; $\mathrm{SEB}$, staphylococcal enterotoxin B 


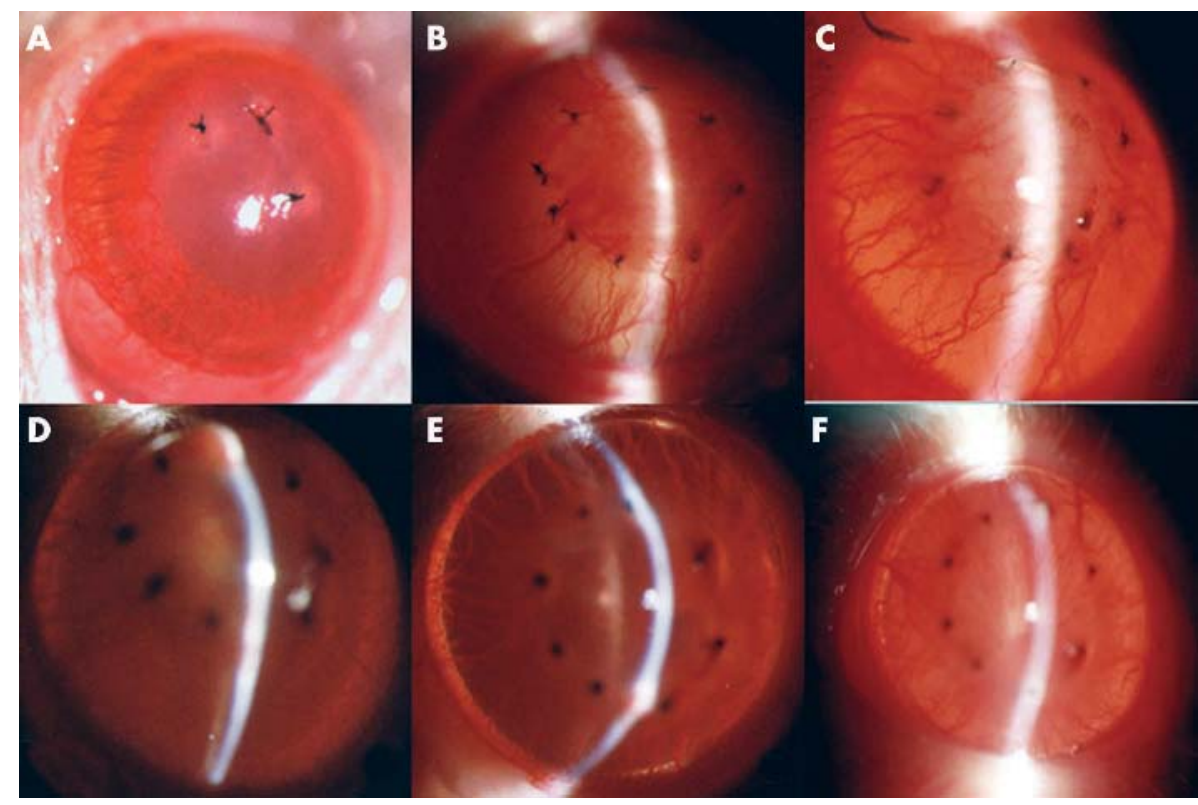

Figure 1 Corneal neovascularisation and clinical evaluation of rat corneal grafts by slit lamp microscope at postoperative day 10. (A) 7 days after suturing, new vessels entered the midperipheral zone of the cornea;

(B) allograft control; (C) $25 \mu \mathrm{g} / \mathrm{kg} \mathrm{SEB}$;

(D) $50 \mu \mathrm{g} / \mathrm{kg} \mathrm{SEB}$; (E) $75 \mu \mathrm{g} / \mathrm{kg} \mathrm{SEB}$;

(F) isografts.

rejection occurred. Then the rat corneas were examined every 2 days. A scoring system was devised to describe the extent of opacity $(0$ to $5+)$ as follows: $0=$ clear graft; $1+=$ minimal superficial (non-stromal) opacity; $2+=$ minimal deep stromal opacity; $3+=$ moderate stromal opacity; $4+=$ intense stromal opacity; $5+=$ maximum stromal opacity. Grafts with opacity scores of $2+$ or greater were considered to have been rejected. ${ }^{10}$

\section{Pharmacological strategy}

All the recipient rats were divided into four groups at random in a masked fashion. Three SEB subgroups were injected intraperitoneally with $0.2 \mathrm{ml}$ SEB at concentrations of $25 \mu \mathrm{g} /$
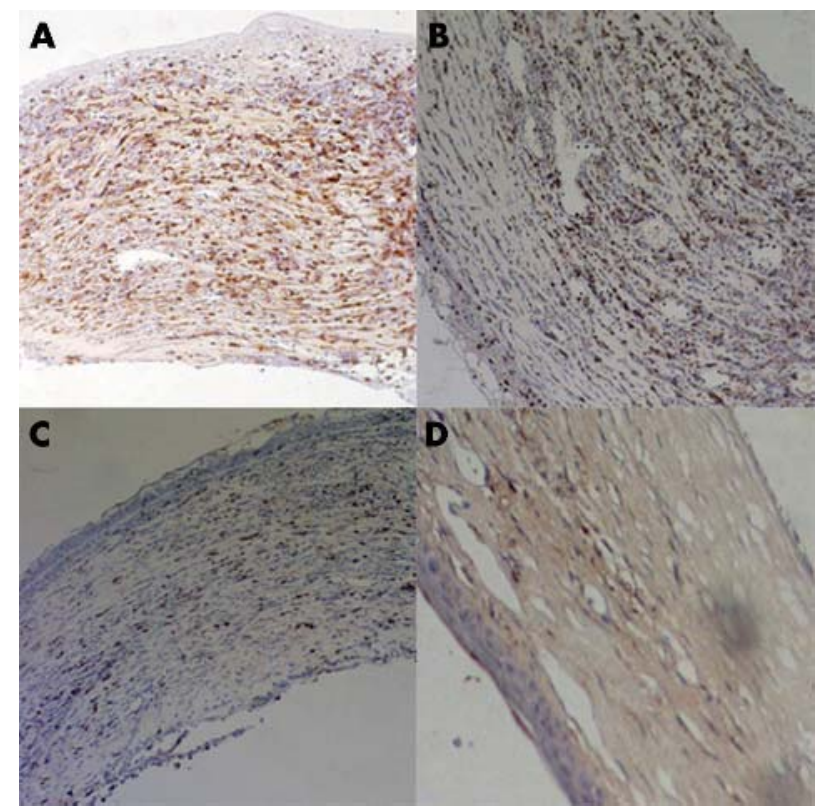

Figure $2 \mathrm{CD}^{+} \mathrm{T}$ lymphocyte infiltration in the rat allograft examined by immunohistochemical staining. The brown staining represents positive CD4 ${ }^{+} \mathrm{T}$ cells. (A) Control group; (B) SEB $25 \mu \mathrm{g} / \mathrm{kg}$ group; (C) SEB $50 \mu \mathrm{g} / \mathrm{kg}$ group; (D) SEB $75 \mu \mathrm{g} / \mathrm{kg}$ group. $\mathrm{kg}, 50 \mu \mathrm{g} / \mathrm{kg}$, and $75 \mu \mathrm{g} / \mathrm{kg}$ before keratoplasty three times at 4 day intervals. The control group received saline buffer in the same way. The day after the third injection, orthotropic corneal transplantation was performed. Meanwhile, four isografts (Lewis to Lewis) were performed to exclude surgical technique errors.

\section{Specimen preparation}

Ten days after keratoplasty, two rats from each group were sacrificed. The eye globes were taken and fixed in 10\% formaldehyde solution for immunohistochemical staining. The blood, spleens, and mandibular lymph nodes were taken for flow cytometry and ELISA assay.

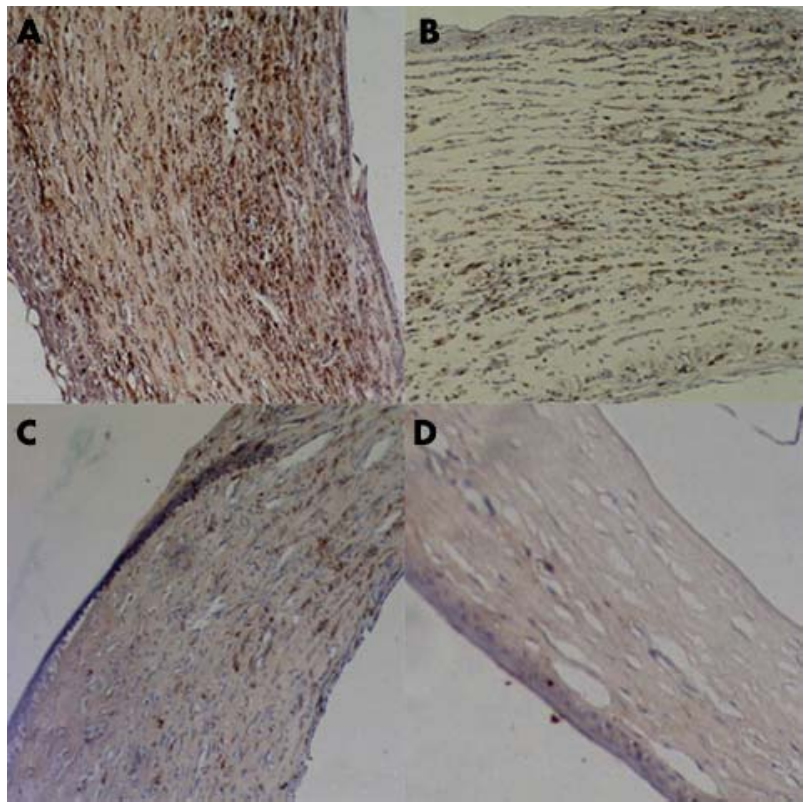

Figure $3 \mathrm{CD}^{+} \mathrm{T}$ lymphocyte infiltration the rat allograft examined by immunohistochemical staining. The brown staining represents positive CD8 ${ }^{+} \mathrm{T}$ cells. (A) Control group; (B) SEB $25 \mu \mathrm{g} / \mathrm{kg}$ group, (C) SEB $50 \mu \mathrm{g} / \mathrm{kg}$ group, (D) SEB $75 \mu \mathrm{g} / \mathrm{kg}$ group. 
Table 1 Comparison of grafts survival time at different concentration of SEB

\begin{tabular}{lclcr}
\hline Groups & No & Survival time (days) & $\begin{array}{l}\text { Median } \\
\text { (min-max, days) }\end{array}$ & $\begin{array}{l}\text { Mean survival time } \\
\text { (mean (SD) days) }\end{array}$ \\
\hline Control & 10 & $8,7,8,7,7,7,8,8,6,7$ & $7(6-8)$ & $7.30(0.67)$ \\
SEB $25 \mu \mathrm{g} / \mathrm{kg}$ & 7 & $8,6,7,5,8,5,6$ & $6(5-8)$ & $6.43(1.27)$ \\
SEB $50 \mu \mathrm{g} / \mathrm{kg}$ & 10 & $8,9,13,10,11,14,14,7,9,12$ & $10(7-14)$ & $10.70(2.50)$ \\
SEB $75 \mu \mathrm{g} / \mathrm{kg}$ & 8 & $10,15,12,13,13,13,12,12$ & $12(10-15)$ & 0.085 \\
Isografts & 4 & $30,30,30,30$ & $30(30-30)$ & 0.001 \\
\hline
\end{tabular}

\section{Immunohistochemical staining}

Monoclonal mouse anti-rat antibodies to CD4 and CD8 were used as primary antibodies (Serotec, UK) and EnVision-HRP (goat anti-mouse, Dako, Glostrup, Denmark) used as a second antibody. Chromogen AEC (Dako) was applied to the tissue staining, followed by counterstaining with Mayer's haematoxylin.

\section{Flow cytometry}

The tissues were milled with a glass slide after the red blood cells were deleted with ammonium chloride solutions and RPMI 1640 culture medium was added. The solutions were filtered with 250 pore Nylon membrane and the single cell solutions were prepared. The cells were then labelled with anti-CD4-perCP, anti-CD8-FITC, and anti-CD16 (NK1.1)-PE fluorescent antibodies (BD Biosciences, Lincoln Park, NJ, USA). The $\mathrm{CD}^{+}, \mathrm{CD}^{+}$, and $\mathrm{CD}^{+} / \mathrm{NKl} .1^{+}$cells were analysed by flow cytometry with a FACScan cytometer (Becton Dickinson Immunocytometry Systems). Cells were gated according to size and scatter to eliminate dead cells and debris from analysis.

\section{Lymphocytes proliferation assay}

The rat spleen cells at a concentration of $5 \times 10^{6} / \mathrm{ml}$ were cultured in 96 well flat bottom tissue culture plates in a volume of $200 \mu \mathrm{l} /$ well and were stimulated with $200 \mu \mathrm{l} \mathrm{ConA}$ (concanavalin-A) at a concentration of $2 \mu \mathrm{g} / \mathrm{ml}$ and with $200 \mu \mathrm{l}$ donor spleen cell antigens (spleen cells at a concentration of $5 \times 10^{6} / \mathrm{ml}$, frozen and melted repeatedly four times). All cultures were performed in quadruplicate, including the control group without mitogen. After 72 hours of incubation, all cultures were pulsed with $10 \mu \mathrm{l}$ methyl thiazolyl tetrazolium (MTT). Five hours later, the optical density (OD) values were measured at a wavelength of $570 \mathrm{~nm}$ by a MRX Microplate reader (Synateck Laboratories, Chantilly, VA, USA).

\section{Cytokines production}

IL-2 and IL-10 levels in the serum were assayed by the enzyme linked immunosorbent assay (ELISA) method. Briefly, 96 well U-bottom microtitre plates were coated with monoclonal anti-rat cytokine antibody (Dako). Then the coated plates were blocked with $2 \%$ bovine serum albumin (BSA). After three washes, the sera were placed into the plates without dilution. Cytokine standards were prepared at various concentrations by serial dilution. Each sample or standard was determined in triplicate. Horseradish peroxidase (HRP) goat anti-rabbit IgG was applied and colour was developed. The OD values were measured in an ELISA kinetics reader at $450 \mathrm{~nm}$ with background subtraction at $630 \mathrm{~nm}$. Results were expressed in $\mathrm{pg} / \mathrm{ml}$ based on standard curves made with recombinant cytokine standards.

\section{Statistics}

Corneal graft rejection was evaluated using a two tailed Fisher's exact test on computer (SPSS for Windows, version 10.0). All data were expressed as mean (SD). A $\mathrm{p}<0.05$ value was deemed statistically significant.

\section{RESULTS}

\section{Incidence and timing of graft rejection}

The mean survival time of the control group was 7.30 (SD $0.67)$ days. SEB at a concentration of $25 \mu \mathrm{g} / \mathrm{kg}$ could not prolong the grafts survival time, but when its concentration was increased to $50 \mu \mathrm{g} / \mathrm{kg}$ and $75 \mu \mathrm{g} / \mathrm{kg}$, the rat allograft survival time could be prolonged significantly, with a concentration of $75 \mu \mathrm{g} / \mathrm{kg}$ having an even better effect. Meanwhile, all four isografts survived more than 30 days and showed no evidence of rejection (table l, fig lB-E).

\section{Lymphocyte infiltration in the allograft}

Ten days after surgery, the grafts in the control group became heavily oedematous and were infiltrated with many $\mathrm{CD} 4^{+}$ and $\mathrm{CD}^{+}$cells. But in the SEB treated groups, there was a significant decrease in lymphocyte infiltration. With the increase in concentration, only a few inflammatory cells were present in the SEB $75 \mu \mathrm{g} / \mathrm{kg}$ group (figs 2, 3).

\section{Subpopulation of lymphocytes in the lymphatic organs}

Compared with the control group, the percentage of $\mathrm{CD}^{+}$ and $\mathrm{CD}^{+} \mathrm{T}$ cells decreased in the spleen and the mandibular lymph node of the SEB treated groups and the SEB $75 \mu \mathrm{g} / \mathrm{kg}$ group was the lowest. In peripheral blood, though the percentage of $\mathrm{CD} 4^{+} \mathrm{T}$ cells in SEB treated groups was higher than in controls, the percentage of $\mathrm{CD}^{+} \mathrm{T}$ cells still decreased with increased concentration. The percentage of $\mathrm{CD}^{+} \mathrm{T}$ cells in the SEB treated groups was lower than in controls and the SEB $75 \mu \mathrm{g} / \mathrm{kg}$ group was the lowest. However, the percentage of $\mathrm{CD}^{+}{ }^{+} \mathrm{NK}$ T cells in the lymphatic organs in the SEB treated

Table 2 The percentage of T cells subpopulation in the lymphatic organs

\begin{tabular}{|c|c|c|c|c|c|c|c|c|c|}
\hline \multirow[b]{2}{*}{ Groups } & \multicolumn{3}{|l|}{ Spleen } & \multicolumn{3}{|c|}{ Peripheral blood } & \multicolumn{3}{|c|}{ Mandibular lymph node } \\
\hline & $\mathrm{CD4}^{+}$ & $\mathrm{CD}^{+}$ & CD4 $^{+}$NK T cells & $\mathrm{CD4}^{+}$ & $\mathrm{CD}^{+}$ & $\mathrm{CD}^{+}{ }^{+} \mathrm{NK} \mathrm{T}$ cells & $\mathrm{CD4}^{+}$ & $\mathrm{CD}^{+}$ & CD4 $^{+}$NK T cells \\
\hline Saline buffer & 39.13 & 13.39 & 1.19 & 30.31 & 20.62 & 1.54 & 65.17 & 5.33 & 0.91 \\
\hline SEB $25 \mu \mathrm{g} / \mathrm{kg}$ & 36.05 & 12.08 & 2.24 & 44.71 & 17.46 & 1.94 & 60.98 & 4.93 & 0.94 \\
\hline SEB $50 \mu \mathrm{g} / \mathrm{kg}$ & 34.30 & 9.20 & 3.57 & 37.03 & 12.53 & 3.39 & 58.98 & 4.45 & 1.51 \\
\hline SEB $75 \mu \mathrm{g} / \mathrm{kg}$ & 33.73 & 8.96 & 4.87 & 36.06 & 11.74 & 5.02 & 38.88 & 3.71 & 2.00 \\
\hline SEB $100 \mu \mathrm{g} / \mathrm{kg}$ & 35.63 & 10.02 & 2.84 & 38.88 & 15.51 & 1.20 & 60.46 & 2.62 & 1.02 \\
\hline
\end{tabular}




\begin{tabular}{|c|c|c|c|}
\hline Groups & Culture medium & ConA $(2 \mu \mathrm{g} / \mathrm{ml})$ & Donor spleen cell antigens \\
\hline Saline buffer & 0.60 & 1.51 & 0.83 \\
\hline SEB $25 \mu \mathrm{g} / \mathrm{kg}$ & 0.61 & 1.44 & 0.81 \\
\hline SEB $50 \mu \mathrm{g} / \mathrm{kg}$ & 0.61 & 0.75 & 0.55 \\
\hline SEB $75 \mu \mathrm{g} / \mathrm{kg}$ & 0.60 & 0.64 & 0.47 \\
\hline
\end{tabular}

groups increased significantly compared with that in the control group (table 2).

\section{Lymphocyte proliferation stimulated by donor antigens}

On the 10th day after keratoplasty, the proliferation ability of the lymphocytes in the control group to ConA and donor lymphocyte antigen was 1.51 and 0.83 , respectively. In the SEB treated groups, the proliferation ability of the lymphocytes was decreased significantly; the higher the concentration of SEB the lower the reaction ability. In the SEB $75 \mu \mathrm{g} / \mathrm{kg}$ group, the reaction ability of the lymphocytes was lowered to only 0.64 and 0.47 , respectively (table 3 ).

\section{Cytokines production in the serum}

With the ELISA method, we could see that the concentration of IL-2 was much lower in the sera of SEB treated groups compared with the control group. With the higher concentration of SEB, the level of IL-2 decreased. However, the concentration of IL-10 was much higher in the SEB treated groups than the control group (fig 4A, B).

\section{DISCUSSION}

There is little doubt that the presence of corneal neovascularisation is a significant risk factor for corneal allograft survival. Under such conditions, the success rate of corneal transplantation was much lower and still very difficult to resolve. ${ }^{12}$ Recent reports showed in vivo administration of SEB resulted in clonal expansion and subsequent deletion of responding $\mathrm{T}$ cells. ${ }^{6}$ In vitro studies showed that the remaining $\mathrm{T}$ cells proliferated poorly upon re-stimulation, suggesting the $\mathrm{T}$ cells were anergic. ${ }^{11}{ }^{12}$

In our experiment the results showed that SEB could prolong the graft survival time. The lymphocyte infiltration in the grafts was also significantly decreased. The percentage of $\mathrm{CD}^{+}$and $\mathrm{CD}^{+} \mathrm{T}$ lymphocytes in the spleen and the mandibular lymph node was also reduced significantly, especially at concentrations of $75 \mu \mathrm{g} / \mathrm{kg}$. We also noticed that the percentage of $\mathrm{CD}^{+}$lymphocytes in blood was reduced by $\mathrm{SEB}$, but $\mathrm{CD}^{+}$lymphocytes rose. One explanation of this phenomenon was because the blood is fluid and lymphatic organs are solid. The other possible cause was that though the percentage of the $\mathrm{CD}^{+}$lymphocytes increased, these cells were actually anergic and could not secret cytokines such as IL-2. ${ }^{12}$ Though the variation of lymphocytes and cytokines in the anterior chamber had not been examined, these results still could prove that SEB may inhibit immune rejection by $\mathrm{T}$ lymphocyte deletion.

Except for lymphocytes numbers reduced by SEB treatment, the proliferation ability of lymphocytes was also minimised, not only to donor antigens but also to ConA, which indicated that SEB could induce non-specific tolerance. Furthermore, IL-2, secreted principally by activated helper $\mathrm{T}$ cells, is an indicator of the activation of T cells. IL-10 could induce the downregulation of MHC class II and decrease the expression of intercellular adhesion molecule 1 (ICAM-1), CD80, and CD86, each of which might be expected to prevent $\mathrm{T}$ cell priming and promote tolerance. ${ }^{13}$ So the higher concentration of IL-10 and the lower concentration of IL-2 induced by SEB treatment might suggest that SEB could induce anergy through the production of Th-2 type cytokines and inhibiting activation of $\mathrm{T}$ cells.

NK T cells belong to a specialised population of leucocytes that co-express TCR $\alpha / \beta$ chain and NK markers. ${ }^{14}$ Several
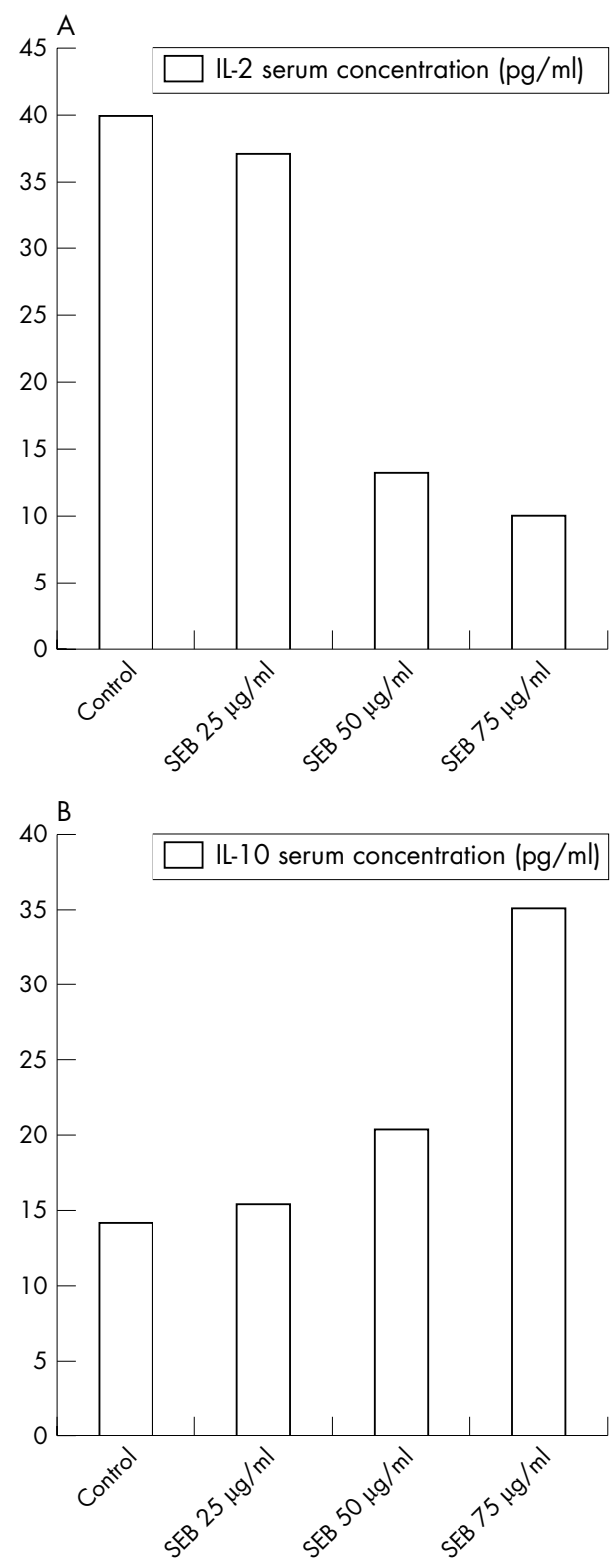

Figure 4 The concentration of IL-2 and IL-10 in the four groups of rat sera at postoperative day 10. (A) IL-2, (B) IL-10. 
reports implied a role for NK $\mathrm{T}$ cells in preventing certain autoimmune diseases and inducing transplantation tolerance. ${ }^{15}{ }^{16}$ Our data showed the percentage in the spleen, the blood, and the mandibular lymph node increased significantly in the SEB treated rats. This might imply that SEB induced anergy bore a close relation to NK T cells.

In summary, SEB could prolong the graft survival time through inducing $\mathrm{T}$ cell deletion and non-specific tolerance in high risk corneal transplantation in rats. The relation between SEB and other immune cells and cytokines in this process still needs to be studied.

\section{ACKNOWLEDGEMENT}

The work was supported by the National Natural Science Foundation of China under project no 3071385.

\section{Authors' affiliations}

Y Jie, W Zhang, Y Wu, L Xu, Beijing Institute of Ophthalmology, TongRen Eye Center, TongRen Hospital, Capital University of Medical Sciences, China

Z Pan, Beijing Institute of Ophthalmology and the Beijing TongRen Eye Bank, TongRen Eye Center, Beijing TongRen Hospital, Capital University of Medical Sciences, China

Y Chen, Department of Immunology, General Hospital of PLA, China Y Wei, Centre Laboratory, Beijing TongRen Hospital, Capital University of Medical Sciences, China

H Peng, Academy of Military Medical Sciences, China

\section{REFERENCES}

1 Niederkorn JY. Immune privilege and immune regulation in the eye. Adv Immunol 1990;48:191-226.
2 Dana MR, Streilein JW. Loss and restoration of immune privilege in eye with corneal neovascularization. Invest Ophthalmol Vis Sci 1996;37:2485-94.

3 Ma D, Mellon J, Niederkorn JY. Oral immunization as a strategy for enhancing corneal allograft survival. Br J Ophthalmol 1997;81:778-84.

4 Niederkorn JY. Immunology and immunomodulation of corneal transplantation. Intern Rev Immunol 2002;21:173-96.

5 Assenmacher M, Löhning M, Scheffold A, et al. Sequential production of IL-2, IFN- $\gamma$ and IL-10 by individual staphylococcal enterotoxin B-activated T helper lymphocytes. Eur J Immunol 1998;28:1534-43.

6 Renno T, Attinger A, Locatelli S, et al. Cutting edge: apoptosis of superantigenactivated T cells occurs preferentially after a discrete number of cell divisions in vivo. J Immunol 1999;162:6312-15.

7 Pan Z, Chen Y, Zhang W, et al. Rat Corneal allograft survival prolonged by the superantigen staphylococcal enterotoxin B. Invest Ophthalmol Vis Sci 2003:44:3346-51.

8 Dana MR, Yamada J, Streilein JW. Topical interleukin-1 receptor antagonist promotes corneal transplant at survival. Transplantation 1997;63:1501-7.

9 Williams KA, Coster DJ. Penetrating cornea transplantation in the inbred rat: a new model. Invest Ophthalmol Vis Sci 1985;26:23-30.

10 Holland EJ, Chan CC, Wetzig RP, et al. Clinical and immuno-histologic studies of corneal rejection in the rat penetrating keratoplasty model. Cornea $1991 ; 10: 374-80$

11 Boles JW, Pitt ML, LeClaire RD, et al. Generation of protective immunity by inactivated recombinant staphylococcal enterotoxin $B$ vaccine in nonhuman primates and identification of correlates of immunity. Clin Immunol 2003;108:51-9.

12 Watson AR, Mittler JN, Lee WT. Staphylococcal enterotoxin B induces anergy to conventional peptide in memory T cells. Cell Immunol 2003;222:144-55.

13 Hanahan D. Peripheral-antigenexpressing cells in thymic medulla: factors in self- tolerance and autoimmunity. Curr Opin Immunol 1998;10:656-62.

14 Sonoda K-H, Stein-Streilein JS. Ocular immune privilege and CDId-reactive natural killer T cells. Cornea 2002;21(2 Suppl 1):S33-8.

15 Thomas SY, Hou R, Boyson JE, et al. CDId-restricted NKT cells express a chemokine receptor profile indicative of Th1-type inflammatory homing cells. $\mathrm{J}$ Immunol 2003;171:2571-80.

16 Lisbonne M, Leite-De-Moraes MC. Invariant Valpha14 NKT lymphocytes: a double-edged immuno-regulatory T cell population. Eur Cytokine Netw 2003; 14:4-14 